\title{
Occupational HIV Transmission Among Male Adult Film Performers - Multiple States, 2014
}

Jason A. Wilken, $\mathrm{PhD}^{1,2}$;; Christopher Ried, $\mathrm{MD}^{3}$; Pristeen Rickett 3 ; Janet N. Arno, MD ${ }^{4}$; Yesenia Mendez ${ }^{5}$; Robert J. Harrison, MD ${ }^{1}$; Dan Wohlfeiler, MJ, $\mathrm{MPH}^{6}$; Heidi M. Bauer, MD ${ }^{6}$; M. Patricia Joyce, $\mathrm{MD}^{7}$; William M. Switzer, MPH 7 ; Walid Heneine, PhD 7 ; Anupama Shankar, MS7; Karen E. Mark, MD, PhD ${ }^{8}$

In 2014, the California Department of Public Health was notified by a local health department of a diagnosis of acute human immunodeficiency virus (HIV) infection* and rectal gonorrhea in a male adult film industry performer, aged 25 years (patient A). Patient A had a 6-day history of rash, fever, and sore throat suggestive of acute retroviral syndrome at the time of examination. He was informed of his positive HIV and gonorrhea test results 6 days after his examination. Patient A had a negative HIV-1 RNA qualitative nucleic acid amplification test (NAAT) ${ }^{\dagger} 10$ days before symptom onset. This investigation found that during the 22 days between the negative NAAT and being informed of his positive HIV test results, two different production companies directed patient $A$ to have condomless sex with a total of 12 male performers. Patient A also provided contact information for five male non-work-related sexual partners during the month before and after his symptom onset. Patient A had additional partners during this time period for which no locating information was provided. Neither patient A nor any of his interviewed sexual partners reported taking HIV preexposure prophylaxis (PrEP). Contact tracing and phylogenetic analysis of HIV sequences amplified from pretreatment plasma revealed that a non-work-related partner likely infected patient $A$, and that patient A likely subsequently infected both a coworker during the second film production and a non-work-related partner during the interval between his negative test and receipt of his positive HIV results. Adult film performers and production companies, medical providers, and all persons at risk for HIV should be aware that testing alone is not sufficient to prevent HIV transmission. Condom use provides additional protection from HIV and sexually transmitted infections (STIs). Performers and all persons at risk for HIV infection in their professional and personal lives should discuss the use of PrEP with their medical providers.

During the first production (a 1-day film shoot on the day before his symptoms began and 9 days after his negative NAAT), Patient A had condomless insertive and receptive anal sex with two HIV-negative performers (contacts 1 and 2) (Table) and condomless receptive and insertive oral sex with

\footnotetext{
* Positive HIV chemiluminescent antigen/antibody test, negative HIV-1/2 rapid immunoconcentrating assay, and quantitative HIV RNA viral load (viral load) $>10 \mathrm{million} / \mathrm{mL}$.

${ }^{\dagger}$ NAAT is a highly sensitive test capable of detecting HIV 10-15 days after infection.
}

four HIV-infected performers (contacts 3-6). Patient A reported that the production company informed him before the film shoot that contacts 3-6 were HIV-infected with undetectable viral loads. During the second production (a 3-day film shoot that began the day after patient A's symptom onset and 11 days after his negative NAAT), patient A had condomless receptive and insertive oral sex and condomless insertive anal sex with three HIV-negative performers (contacts 7-9), and condomless receptive and insertive oral sex with three HIV-negative performers (contacts 10-12).

After obtaining consent from patient $\mathrm{A}$, local health department staff contacted the two production companies and obtained contact information for each of his work-related sexual partners. The performers and patient A's non-workrelated sexual contacts lived in seven U.S. states and four foreign countries. The production companies were based in two other states, and filming occurred in yet another state. The local or state health department of each performer confidentially notified all eight performers previously known to be HIV-negative, two performers previously known to be HIV-infected, and all five named non-work-related sexual partners to inform them of their potential HIV and gonorrhea exposures. Two other performers previously known to be HIV-infected could not be located. All persons contacted were offered immediate and follow-up (30-day) HIV NAAT and STI testing. Pre-treatment plasma was collected from patient A and all his contacts with newly diagnosed HIV infections. Using established methods (1), HIV-1 polymerase (pol; 997-bp) and p17 gag (gag; 411-bp) sequences were independently polymerase chain reaction-amplified from plasma specimens.

Among patient A's work-related sexual contacts from the first film production, contacts 1 and 2 had negative HIV NAATs 62 and 53 days after filming, respectively, indicating that patient A did not infect any work-related sexual contacts from the first film production. Contact 4 received a diagnosis of early latent syphilis 13 days after filming, and contact 2 received a diagnosis of genital chlamydia infection 23 days after filming. No evidence of prefilming HIV testing was made available to investigators from this production company.

Among patient A's work-related sexual contacts from the second film production, contact 7 (hereafter referred to as patient B) experienced fever and sore throat suggestive of 
TABLE. Occupational and nonoccupational exposure to and transmission of HIV among contacts* of a male adult film performer (patient A) — multiple states, 2014

\begin{tabular}{|c|c|c|c|c|c|c|c|c|}
\hline $\begin{array}{l}\text { Contact no. } \\
\text { (Patient ID) }\end{array}$ & $\begin{array}{l}\text { Setting of sexual } \\
\text { contact with } \\
\text { patient A }\end{array}$ & $\begin{array}{l}\text { HIV status at last sexual } \\
\text { contact with patient } A\end{array}$ & $\begin{array}{l}\text { Type of sexual contact } \\
\text { with patient } A\end{array}$ & $\begin{array}{c}\text { Day of last } \\
\text { sexual contact } \\
\text { with patient } A^{\dagger}\end{array}$ & $\begin{array}{l}\text { Day of last } \\
\text { negative } \\
\text { HIV test }\end{array}$ & $\begin{array}{c}\text { Day of } \\
\text { symptom onset }\end{array}$ & $\begin{array}{l}\text { Day of } \\
\text { positive } \\
\text { HIV test }\end{array}$ & STIs ${ }^{\S}$ \\
\hline$(A)^{*}$ & - & - & - & - & $6^{\dagger}$ & $16^{\text {q }}$ & $28 \pi$ & Rectal GC \\
\hline 1 & Film production 1 & Negative & Condomless anal I/R & 15 & $62^{* *}$ & - & - & \\
\hline 2 & Film production 1 & Negative & Condomless anal I/R & 15 & $53^{* *}$ & - & - & Genital CT \\
\hline 3 & Film production 1 & $\begin{array}{l}\text { Chronically infected, } \\
\text { VL undetectable }\end{array}$ & Condomless oral I/R & 15 & - & - & - & \\
\hline 4 & Film production 1 & $\begin{array}{l}\text { Chronically infected, } \\
\text { VL undetectable }\end{array}$ & Condomless oral I/R & 15 & - & - & - & $\begin{array}{l}\text { Early latent } \\
\text { syphilis }\end{array}$ \\
\hline 5 & Film production 1 & $\begin{array}{l}\text { Chronically infected, } \\
\text { VL undetectable }\end{array}$ & Condomless oral I/R & 15 & - & - & - & \\
\hline 6 & Film production 1 & $\begin{array}{l}\text { Chronically infected, } \\
\text { VL undetectable }\end{array}$ & Condomless oral I/R & 15 & - & - & - & \\
\hline $7(B)^{*}$ & Film production 2 & Negative & $\begin{array}{c}\text { Condomless oral I/R; } \\
\text { Condomless anal R }\end{array}$ & 17 & - & $4^{* *}$ & $18^{* *}$ & \\
\hline 8 & Film production 2 & Negative & $\begin{array}{l}\text { Condomless oral I/R; } \\
\text { Condomless anal R }\end{array}$ & 17 & $36^{* *}$ & - & - & \\
\hline 9 & Film production 2 & Negative & $\begin{array}{l}\text { Condomless oral I/R; } \\
\text { Condomless anal R }\end{array}$ & 17 & $14^{* *,+\dagger}$ & - & - & \\
\hline 10 & Film production 2 & Negative & Condomless oral I/R & 17 & $30^{* *}$ & - & - & \\
\hline 11 & Film production 2 & Negative & Condomless oral I/R & 17 & $57^{* *}$ & - & - & \\
\hline 12 & Film production 2 & Negative & Condomless oral I/R & 17 & $16^{* *, t \dagger}$ & - & - & \\
\hline $13(C)^{*}$ & Non-work & Negative & $\begin{array}{l}\text { Condomless oral I/R; } \\
\text { Condomless anal I/R }\end{array}$ & 24 & - & $15^{* *}$ & $16^{* *}$ & $\begin{array}{l}\text { Rectal CT, } \\
\text { latent syphilis }\end{array}$ \\
\hline 14 & Non-work & $\begin{array}{l}\text { Chronically infected, } \\
\text { VL undetectable }\end{array}$ & $\begin{array}{l}\text { Condomless oral I/R; } \\
\text { Condomless anal I/R }\end{array}$ & 22 & - & - & - & \\
\hline 15 & Non-work & Negative & $\begin{array}{l}\text { Condomless oral I/R; } \\
\text { Condomless anal I/R }\end{array}$ & 24 & $16^{* *,+十}$ & - & - & Rectal CT \\
\hline $16(D)^{*}$ & Non-work & $\begin{array}{l}\text { Chronically infected, } \\
\mathrm{VL}=127,000 \text { copies } / \mathrm{mL}^{\S \S}\end{array}$ & $\begin{array}{l}\text { Condomless oral I/R; } \\
\text { Condomless anal I/R }\end{array}$ & 0 & - & unknown & $47^{* *}$ & Pharyngeal CT \\
\hline 17 & Non-work & Negative & $\begin{array}{l}\text { Condomless oral I/R; } \\
\text { Condomless anal I/R }\end{array}$ & $\sim-20$ & $\sim 38^{* *}$ & - & - & Rectal GC \\
\hline
\end{tabular}

Abbreviations: - = not applicable; $\mathrm{CT}=$ chlamydia; $\mathrm{GC}=$ gonorrhea; $\mathrm{HIV}=$ human immunodeficiency virus; $\mathrm{I}=$ insertive; $\mathrm{R}=$ receptive; $\mathrm{STI}=$ sexually transmitted infection; $\mathrm{VL}=$ viral load.

* Letters in parentheses indicate patient $A$ and his contacts who became patients during the investigation.

† Relative to patient A's last sexual contact with patient D (source case).

$\S$ At time of HIV test.

I Relative to last sexual contact with patient $\mathrm{D}$.

** Relative to last sexual contact with patient A.

${ }^{t+}$ Refused subsequent HIV testing.

$\S \S \mathrm{VL}$ was measured 46 days after last sexual contact with patient $A$.

acute retroviral syndrome 4 days after filming concluded, and received a diagnosis of acute HIV infection 18 days after filming. ${ }^{\$}$ Contacts 8,10 , and 11 tested negative by HIV NAAT 36, 30, and 57 days, respectively, after filming. Contacts 9 and 12 tested negative by HIV NAAT 14 and 16 days, respectively, after filming, but refused subsequent HIV NAAT testing. All six performers from the second production (patient $B$ and contacts $8-12$ ) had recent, documented HIV-negative testing before the second film production (contacts $8-12$ had a documented negative HIV-1 NAAT 3-10 days before filming, and Patient B had a negative immunochemiluminometric HIV-1/2 antibody 3 days before filming).

\footnotetext{
$\$$ Negative HIV-1/2 immunochemiluminometric antibody, HIV viral load $>10$ million $/ \mathrm{mL}$
}

Patient A was the only performer common to both productions. He reported no non-work-related sexual contact with performers from either production company. Patient B reported non-work-related sexual contact with one performer (contact 11) from the second film production company after filming was completed.

During the 1 month before as well as after symptom onset, patient A engaged in condomless insertive and receptive oral and insertive and receptive anal sex with five named male non-work-related partners (contacts 13-17). Based on dates of sexual contact, contacts 13-15 were considered at risk for infection (i.e., potential spread partners), and contacts 16 and 17 were considered potential sources of patient A's HIV infection. Among non-work-related potential spread partners, contact 13 had multiple sexual contacts with patient A during the 8 days 
after patient A's symptom onset. Contact 13 was HIV NAATnegative 5 days after his last sexual contact with patient $A$, but was found to have rectal chlamydia and latent syphilis. However, 15 days after his last sexual contact with patient A, contact 13 experienced onset of sore throat, fever, and body aches suggestive of acute retroviral syndrome. Contact 13, hereafter referred to as patient $\mathrm{C}$, received a diagnosis of acute HIV infection 1 day after his symptom onset. Contact 14 had sexual contact with patient A 6 days after patient A's symptom onset and was previously known by his local health department (but not to patient A) to be HIV-infected, on treatment, and to have an undetectable viral load. Contact 15 had sexual contact with patient A 8 days after patient A's symptom onset, had a negative HIV Ag/Ab chemiluminescent antigen/antibody test, and received a diagnosis of rectal chlamydia infection 16 days after their last sexual encounter; subsequent HIV test results for contact 15 are not available.

Patient A had non-work-related sexual contact with contact 16 six days before Patient's A's negative NAAT. Forty-seven days after his last sexual contact with patient A, contact 16 (hereafter referred to as patient D) received a diagnosis of pharyngeal chlamydia and previously unrecognized chronic HIV infection through laboratory methods.** Patient D identified a potential spread partner, a man who also was subsequently determined to have previously unrecognized chronic HIV infection; pretreatment plasma was not obtained from this patient for phylogenetic analysis of viral sequences. Patient A also had non-work-related sexual contact with another man (contact 17) approximately 1 month before symptom onset; Contact 17 had a negative NAAT but received a diagnosis of rectal gonorrhea $>30$ days after his last sexual contact with patient $\mathrm{A}$.

Phylogenetic analysis of the pol and gag sequences revealed that patients $A, B, C$, and $D$ all had subtype $B$ sequences that clustered tightly together suggesting high genetic relatedness of their HIV sequences. Pairwise nucleotide identities $(99.1 \%$ in gag and $99.6 \%$ in $p o l$ ) were high. None of the polsequences had any major drug resistance mutations. Patients A, B, C, and D were all linked to care within 18 days of receiving their diagnoses.

\section{Discussion}

Since the 1990s, many adult film production companies have required performers to participate in periodic HIV testing. In 2004, work-related HIV transmission between heterosexual adult film performers (2) occurred despite the existence of one

\footnotetext{
S Positive HIV Ag/Ab chemiluminescent antigen/antibody test, negative HIV-1/2 immunoconcentrating assay, and viral load $>10$ million $/ \mathrm{mL}$.

** Positive HIV rapid immunoassay and HIV-1/2 enzyme immunoassay; CD4 count $=384$ cells $/ \mathrm{mm} 3$, HIV viral load $=127,000$ copies $/ \mathrm{mL}$.
}

such testing program. Many adult film production companies continue to rely on HIV testing as the primary method to prevent HIV transmission. Performers obtain an HIV NAAT through a commercial laboratory, their test results are maintained in a database by a third party, and production companies check this database to ensure that performers have had a recent negative test before filming. To partially protect performer privacy, production companies are only informed of whether a performer is cleared to perform or not on the basis of test results. Some production companies have specialized in producing "bareback" films which involve condomless anal sex among male performers. Patient A had testing with NAAT $<14$ days before filming, as recommended by a leading industry trade group, with negative results. However, patient A's acute retroviral syndrome onset occurred 10 days after his NAAT and he engaged in condomless insertive and receptive oral, and insertive anal sex with patient $B$ as directed by the production company.

The Federal Occupational Safety and Health Administration (OSHA) requires that all employers provide a place of employment free from recognized hazards that are causing, or are likely to cause, death or serious physical harm to employees. ${ }^{\dagger \dagger}$ The California state standard, equivalent to the OSHA Bloodborne Pathogens standard, requires that employers must include consistent use of appropriate engineering, administrative, and work practice controls, and personal protective equipment to prevent contact with blood and other potentially infectious materials, including semen and vaginal secretions. ${ }^{\$ \$}$ Adult film performers are at risk for these work-related exposures (3).

In 2012, voters in Los Angeles County passed a local law requiring that adult film performers wear condoms during vaginal and anal sex and requiring adult film production companies to obtain a film permit from the Los Angeles County Department of Public Health. Permitting requirements include completion of a bloodborne pathogen training course by adult film directors, and submission of an exposure control plan by adult film producers. 99

\footnotetext{
$\dagger^{\dagger \dagger} 29$ U.S.C. Section 651. Furthermore, in California, adult film performers may be considered employees under the law. See Deupree v Workers' Comp. Appeals Bd., 2008 WL 4191236 (Cal. App. 2d Aug. 19, 2008); California Occupational Safety and Health Appeals Board, in the matter of the appeal of Cybernet Entertainment, LLC dba Kink.com, dockets 14-R6D1-0364 through 0367. April 10, 2015. http://www.dir.ca.gov/oshab/DECISIONS-ALJ/2015/ Cybernet_Entert_2014-6-1-0364.pdf; and California Occupational Safety and Health Appeals Board, in the matter of reconsideration of the appeal of Treasure Island Media, Inc., dockets 14-R6D1-1093 through 1095. August 13, 2015. http://www.dir.ca.gov/oshab/decisions/Treasure-Island-Media.(10-1093).pdf.

$\$ \$ 29$ CFR, Section 1910.1030, Bloodborne Pathogens. https://www.osha.gov/ pls/oshaweb/owadisp.show_document?p_table=STANDARDS\&p_id=10051; and California Code of Regulations, Section 5193, Bloodborne Pathogens, http://www.dir.ca.gov/title8/5193.html.

99 Los Angeles County Health and Safety Code, Title 11, Chapter 11.39, Safer Sex in the Adult Film Industry. https://www.municode.com/library/ca/los_ angeles_county/codes/code_of_ordinances.
} 


\section{Summary}

What is already known on this topic?

Work-related transmission of human immunodeficiency virus (HIV) and other sexually transmitted infections has been documented among adult film performers. HIV tests, including nucleic acid amplification, do not detect HIV very early after infection.

What is added by this report?

This is the first well-documented work-related HIV transmission among male adult film performers. A performer was infected by a non-work-related partner who was not aware of his HIV infection. The performer, having tested negative by nucleic acid amplification test within the preceding 14 days, and unaware of his very recent HIV infection, infected another performer and a non-work-related partner. Viruses in all four HIV infections were highly genetically related, indicating a transmission cluster.

What are the implications for public health practice?

Federal and state Occupational Safety and Health Administration regulations delineate rights of employees and responsibilities of employers to ensure safe working conditions. The adult film industry is well suited for implementation of combination HIV prevention strategies including biomedical (HIV testing, treatment, and preexposure prophylaxis), behavioral (consistent and correct use of condoms, facilitated by the use of a compatible lubricant), and regulatory interventions.

In May 2015, the California Occupational Safety and Health Standards Board held a public hearing on proposed new workplace standards to prevent STIs in the adult film industry, which included specific requirements for consistent and correct condom use (facilitated by the use of a compatible lubricant), and for confidential medical services provision at the employer's expense, including HIV and STI testing, and hepatitis $\mathrm{A}$ and human papillomavirus vaccinations, in addition to existing requirements for hepatitis $B$ vaccination (4). The specific testing and examinations performed and their results would only be available to the performer, the health care provider, and anyone designated by the performer.

The wide geographic distribution of adult performers, filming locations, and production companies highlights the challenges of developing adult film worker protection regulations on a national and global scale, conducting contact investigations, and disseminating prevention information to employers and employees. Because the adult film industry recruits workers from numerous states and countries, documenting future disease transmission associated with filming sexual acts might, as this investigation did, require substantial resources and coordination between local, state, and federal agencies.

Because follow-up testing has not been reported for some sexual partners of patient $A$, and patient $A$ did not reveal the names of all of his sexual contacts, this report might underestimate the extent of HIV transmission in this cluster. Among patient A's 17 named sexual contacts, six were chronically HIV-infected, one had last sexual contact with patient A before patient $A$ was infected, and 10 were at risk for infection by patient $A$. Seven of these 10 engaged in condomless receptive anal sex with patient $\mathrm{A}$, and two became infected. This $29 \%$ attack rate is comparable to the $23 \%$ attack rate of work-related HIV transmission among heterosexual performers in the 2004 report (2).

None of the interviewed persons in this sexual network used HIV PrEP, despite being at high risk for HIV infection. Coformulated emtricitabine/tenofovir (Truvada) has federal Food and Drug Administration approval to be taken orally once daily by HIV-negative persons for PrEP. Maximal intracellular concentrations of tenofovir are reached in rectal tissue at approximately 7 days, and in cervicovaginal tissues at approximately 20 days (5). Efficacy depends on adherence, but is $>90 \%$ effective if taken daily. Unlike condoms, PrEP is not an HIV prevention modality with which employers can ensure compliance because of the requirement for daily use outside of the workplace, with no methods of tracking; PrEP also does not prevent other STIs. However, combined with condoms, PrEP remains an important approach for preventing HIV infection among persons at high risk for HIV infection, including adult film industry performers who might be at risk in both their professional and personal lives.

This investigation emphasizes the importance of public health prevention and regulatory strategies to prevent occupational HIV and other STI transmission. Persons at high risk for HIV infection should receive periodic HIV and STI testing. ${ }^{* * *}$ However, as demonstrated here and previously among heterosexual adult film performers (2), testing alone is not sufficient to prevent occupational HIV transmission. HIV can be transmitted during the 14-day period after a negative NAAT test, before a positive test is obtained. PrEP significantly reduces the risk for HIV acquisition among HIV-negative persons at high risk; however, PrEP is not an intervention with which employers can ensure compliance, and should be used with condoms to protect against both HIV and other STIs. The high prevalence of STIs within this network of sexual partners, including performers, emphasizes the importance of consistent condom use. In addition to complying with regulatory requirements under OSHA standards, the adult film industry should consider the implementation of combination HIV prevention strategies, including biomedical (HIV testing, treatment, and PrEP) and behavioral (consistent and correct use of condoms) interventions.

\footnotetext{
*** http://www.cdc.gov/hiv/pdf/prepguidelines2014.pdf; http://www.cdc.gov/ $\mathrm{std} / \operatorname{tg} 2015 /$ screening-recommendations.htm.
} 


\section{Acknowledgments}

Disease investigation staff members of the Colorado, Florida, Georgia, Indiana, Michigan, New York, New York City, Texas, San Diego, and Sonoma County, California health departments.

${ }^{1}$ Occupational Health Branch, California Department of Public Health; ${ }^{2}$ Division of State and Local Readiness, Office of Public Health Preparedness and Response, CDC; ${ }^{3} \mathrm{HIV} / \mathrm{STD}$ Program, Orange County Health Care Agency, Santa Ana, California; ${ }^{4}$ Indiana University School of Medicine; ${ }^{5}$ Colorado Department of Public Health and Environment; ${ }^{6}$ STD Control Branch, California Department of Public Health; ${ }^{7}$ Division of HIV and AIDS Prevention, National Center for HIV, Hepatitis, STD, and TB Prevention, CDC; ${ }^{8}$ Office of AIDS, California Department of Public Health.

Corresponding authors: Jason A. Wilken, jwilken@cdc.gov, 510-620-3622; Christopher Ried, cried@ochca.com, 714-834-8598.

\section{References}

1. Ivanov IA, Beshkov D, Shankar A, et al. Detailed molecular epidemiologic characterization of HIV-1 infection in Bulgaria reveals broad diversity and evolving phylodynamics. PLoS One 2013;8:e59666. http://dx.doi. org/10.1371/journal.pone.0059666.

2. Taylor MM, Rotblatt H, Brooks JT, et al. Epidemiologic investigation of a cluster of workplace HIV infections in the adult film industry: Los Angeles, California, 2004. Clin Infect Dis 2007;44:301-5. http://dx.doi. org/10.1086/510487.

3. Gold D. An industrial hygienist looks at porn. J Occup Environ Hyg 2015;12:D184-90. http://dx.doi.org/10.1080/15459624.2015.1053895.

4. California Department of Industrial Relations. Sexually transmitted infections. https://www.dir.ca.gov/oshsb/Sexually_transmitted_infections.html.

5. Anderson PL, Kiser JJ, Gardner EM, Rower JE, Meditz A, Grant RM. Pharmacological considerations for tenofovir and emtricitabine to prevent HIV infection. J Antimicrob Chemother 2011;66:240-50. http://dx.doi. org/10.1093/jac/dkq447. 